\title{
Approach to the Prevention Counseling in the Habit of Smoking on Athletes
}

\author{
Donie \\ Sport Coaching Education Program, Faculty of Sport Science, Universitas Negeri Padang, Indonesia \\ *Corresponding author. Email: donie.fik.unp@gmail.com
}

\begin{abstract}
Cigarettes is one of the problems that dilemma. On one side of existence is the livelihood and source of foreign exchange of the country, on the other hand smoking is one cause of health problems. Among young people, especially athletes, smoking is problematic for parents and coaches, and most coaches forbid cigarettes for athletes to eat. It takes various Efforts to Prevent and avoid the habit of smoking to athletes, one of them through a counseling approach, so that problems of smoking among athletes can be prevented and avoided.
\end{abstract}

\section{Keywords: Smoking, Counseling Approach}

\section{INTRODUCTION}

Thesuccessful coach is usually the coach is very concerned athletes-athletes and have the ambition to win. Many coaches have failed in its duty by being too eager to win but did not pay attention. More to that shape the character and personality of the athlete to be human resilient, healthy and resilient to be a challenge and responsibility of a coach.

The coach must be able to explore the potential of individuals so that they can solve their own problems which the coach acts as a facilitator [1]. The coach also shape the character and mental. Character and mental athletes expected are as follows: 1) Sportive, perseverance and discipline, 2) Has the stabilization of emotions in any situation, 3) Confident, 4) Healthy Living, moralists and harmonious, 5) Ability to develop muscle function and physiology, 6) Always develop themselves.

Coach is a label which emits a courtesy, respect, status, responsibility. Mentions coach can often be continued even if the task as a coach is over. Once we become a coach, forever we are trainers for our athletes, for the community. Athletes assume that the coach is the expert in all things and good at playing a variety of roles, so many athletes who want to be like his coach that he would become a coach.

Although some are not wanted and vowed never to do as the coach first. But what they have learned from coach will impress upon athletes. Every coach should always be aware of and understand the objectives to be achieved and the ultimate goal of an exercise to improve performance, and as far as possible to get the victory in the match. It becomes very important, but the coaches should be aware also that the more important is the increase in the athlete's performance and personal development of athletes. Athlete's mental and personality development is strongly influenced by the personality of the coach (Eaton, 2008).
Rationale The lifting of this paper is on the research results PuputPrasetiawan [2] related to the results of a study of high school students in a district which concluded that counseling can help overcome the various problems faced by students both in terms of smoking habits of students as well as other problems that may be faced by the students, including knowledge, attitudes and motivation of students to avoid smoking. This of course can be referenced handling of cases of smoking in athletes.

\section{METHODOLOGY}

This writing is a case study which according to [3] explain that the case studies should be trying to test the unit or individual in depth. Researchers are trying to find all the important variables [4]. In this case related to the factors affecting athletes smoked.

\section{RESULT}

There is a very talented badminton athletes with the best achievements of the whole athletes who practice it. Nearly exhausted most of the time he used to practice every day. Although athletes are not too good in the academic values, but at the club where she practiced her is the most accomplished player

Place these athletes practicing some peers also look diligently practicing under the guidance and coach. The coach is trying to instill a good lifestyle, and attitudes commendable that athletes can grow and develop into a good athlete, a member of the public good where of course the pattern of attitude of an athlete that is discipline, a healthy lifestyle and hard work could be applied by athletes in everyday life.

Something that is often emphasized by the coaches is a pattern of healthy living that is so that athletes not to smoke. Coaches realize very well that smoking is not good for the health of the athletes and appearance, smoking can 
be bad to the athlete's psychological, one of which can cause dependence athletes. So the coaches made a firm rule and awarding sanctions against athletes who are caught smoking.

But on one occasion following the match outside the province, the coach accidentally found cigarettes in a bag racket best athletes and coaches' flagship is increased shocked after checked some of the bags athletes also found a package of cigarettes. The coach slumped as if in disbelief that the athlete who has her guard and coached well turn out to have been untouched by smoking. In the club provision established that smoking is a grave error for the athletes and should be subject to sanctions which are quite loud. The coach feels trapped in a difficult choice between enforcing discipline with penalties to the athlete or perform preventive steps so that athletes in the building is not trapped and protracted in the problems habit that cigarette

Smoking is one habit that is encountered in everyday life , Lifestyle or life style is attractive as a health problem, at least regarded as risk factors of a disease is not contagious. Approximately 25 types of infectious diseases attack humans caused by smoking such as mouth cancer, esophagus, pharynx, larynx, lung, pancreas and bladder [5].

The study shows that heavy smokers have started this habit since I was a teenager, and hardly there are heavy smokers who start smoking as adults. Therefore, adolescence is often considered to be a critical mass that determines whether we will become a smoker or not [3].

Direct effects experienced by people who smoke, for example: the activity of the brain and nervous system which initially increases and then decreases, the feeling of mild euphoria, feeling relaxed, increased blood pressure and heart rate, decreased blood flow to the limbs such as fingers and feet, dizziness, nausea, watery eyes, stomach acid increased, decreased appetite, and loss of sense of taste and smell.

Most teens start smoking related to the psychosocial aspects of the crisis experienced in the development period, ie the period when they were looking for their identity. In adolescence, often described as a time of storms and hurricanes due to mismatches between the psychic and social development. Efforts to determine the identity of these, not all can be run in accordance with the expectations of society. Some teens do as a way of compensatory smoking behavior. For adolescent smoking behavior is the behavior of symbolization. The symbol of maturity, strength, leadership, and attractiveness to the opposite sex.

A study results mentioned that some of the factors that cause a person to smoke teenagers such as: personal factors or personality, social influence, taste and feeling, psychological factors such as stress, control anger, keeping weight, so that concentration, denial and get inspiration [6]. Another study also found some causes of teenage smoking, among others, the influence of peers, a friend who is naughty, curiosity, the desire to fit in with friends, eliminates frustration, imitating older people are the main cause pushing the habit of smoking among adolescents. In the study found that curiosity is the dominant factor $(43.8 \%)$ encourages teens to smoke [3]. As for other factors that causes teens to smoke among them:

\section{Influence of Parents}

Influence of parents, like father, greatly affects the behavior of the children in the home, including the habit because it mimics smoking fathers. Unfortunately, many people have a bad influence on young children and did not realize that it will affect them later on in the future. This is a common problem in families who do not understand the meaning of education, especially in the younger generation. They should be aware that children tend to have a habit of copying what adults do [7]. Because children may find a figure of adults, especially the closest thing that a parent. Parents may think smoking is trendy, yet unconsciously influence the child to imitate the behavior of Personality Factors

People try to smoke because of the curious or want to escape from physical pain or soul, freeing yourself from boredom. One personality trait that is predictive of user on drugs (including smoking) is social conformity. A child with a closed private are more likely to get other fugitives in the form of things that sometimes damage themselves, including one starting with the habit of smoking.

\section{Influences of Ads}

Viewed mass media advertising and electronic display the picture that smokers are the symbol of virility or glamor, make teenagers often triggered to follow the behavior as it exists in the ad. Although the ad eased business now through one slogan and pictures warning of the dangers of smoking. This step is considered quite effective because of the results of a study of $92.3 \%$ of respondents stated aware of the slogan and the image created (Marahmat, 2012).

\section{Environmental Factors}

Related to tobacco use, among others, parents, siblings and peers who smoke, exposure to tobacco billboards, artist on tobacco advertisement in the media. Parents play an important role, but it is also the advertisement of tobacco is estimated to have a stronger influence than the influence of parents or peers, it is probably because it affects students' perceptions of appearance and benefits of cigarettes.

\section{Idol Factor}

In the sports world many great athletes have a high dependence with smoking, the impact is as bad as a public figure who'sbehavior and follow its horns is something that gets the attention of his fans including also a less good habit habits such as consuming cigarettes. Some great athletes that have a problem with smoking in them are: Johan Cruyff; Is the legend of the Netherlands and Barcelona, but he will also be remembered for in 1991 had to undergo heart surgery due to his hobby of spending 20 cigarettes per day, he experienced it as a coach of Barca, in the dressing room he always sucked it up When serving the reporters, but now he has been recognized and no 
longer want to continue his hobby was, and instead be activists who promote the dangers of smoking.

Maradona is one of the great names who have a penchant for sucking on cigarettes and cigars, but he also recently started it after retiring from the field of green, his penchant for these somewhat reduced current, as in 2004, she had to spend 10 days intensive care because he had trouble breathing disorder.

Zinedine Zidane be a lot that is not expecting it, the gods of football turns out also so familiar with the tobacco, he never caught on camera was talking to smoke the moment ahead of the Semi Final match of the 2006 World Cup, against Portugal, ironically in the year 2002 he became the main character in an anti-smoking campaign, it appears that it is increasingly justify the term which reads A France should smoke.

Legendary Brazil Captain Socrates who ushers in the Samba world champion, professed himself often spends two packs of cigarettes per day during his career on the gridiron, he continues his habit after retirement, and although now $\mathrm{He}$ became a medical personnel, ironic indeed, health experts are not aware of the health.

\section{Influence of Smoking on quality Physical athletes}

Smoking will affect the physical fitness level of athletes is lower than not athletes smokers. This happens because the oxygen supply is reduced because hemoglobin binds oxygen in the blood, will be more dominant than the carbon monoxide binds with oxygen so that during exercise a smoker will quickly panting to meet the needs and the optimal oxygen.

If for a sportsman, which requires oxygen supply as much for durability. If a smoke 10-12 cigarettes a day, then sometimes the amount of oxygen supplied to the tissues of our bodies decline of approximately $5 \%$. Decreased oxygen levels that are not so visible signs at the time of smokers rest.

A study conducted by [8] and his comrades against 298 people aged 20-29 years shows that smoking turned out to affect the heart rate of young smokers, increasing the pulse rate at rest, slow increased pulse rate during exercise and interfere with their ability to achieve maximum pulse rate.

\section{Implementation of Athlete Counseling Service in Question with Cigarette}

Birth of a champion can not be separated from the role of coach. The athlete with the talent is the basis demeanor birth of a champion. Fierce competition in the sport today has involved scientists from various disciplines. So as to be able to win the game is not enough to capitalize talent and absolutely necessary assistance from various disciplines and coaches are the main holders.

Coaching is a business or activity giving treatments (treatments) to help athletes to ultimately athletes can develop themselves and improve the ability of talent, skill, physical condition, knowledge, attitudes, control of emotions and personality in general.

In sports athletes are expected to do as well as possible which means that his personal ability to function well in a certain level of integrity and demonstrate emotional maturity and self control. Opinions of experts generally show the same trend, namely that exercise can have a positive effect on the individual as increased responsibility, honesty in the play, care for others, leadership, respect for coaches, referees, and coaches, loyal, tolerance, discipline that ultimately can expected to be a good citizen.

The term comes from the Latin counseling, namely"Concilium"which means "with" or "together" strung with "accept" or "pass". That helps people to be aware of themselves and react to environmental influences it receives. Furthermore, the relevant help determine some personal meaning for such behavior, and develop and clarify the goals and values of for his behavior in the future. Counseling is a process to help individuals overcome barriers to their development, and to achieve the optimal development of personal capabilities it has, the process happens every time.

Expert guidance and counseling professionals named Prayitno, believes counseling is the process of providing assistance or services provided to an individual either children or adults in order to develop the skills themselves independently, by harnessing the power of individuals and facilities that exist and are developed based on the norms in force [9].

Counselling services were organized with the orientation, principles and basic integrated is one of the important things that should also get attention from the coaches. Because the training is not always as we want, our athletes are not always foster running in accordance with the patrons we have set. As a teenage athlete in times of change often found clash-clash and violation infringement of yesteryear, where one of them is the behavior and habit of smoking among athletes.

Some of the principles that need to be considered are: 1) The function of understanding the function help participants understand themselves and the environment; 2) Prevention function, namely a function to assist learners are able to prevent or avoid themselves from the various problems that can hamper their development; 3) The function of Poverty, which functions to help learners overcome the problem; 4) Maintenance and Development function, which is a function to help learners maintain and potential and its positive conditions; 5) The function of Advocacy, which functions to help learners acquire the defense of the rights or interests which have received less attention [10]

For the coaches need to pay attention to the orientation that is the direction of attention and focus that must be considered in the implementation of counseling services include:

Individual Orientation means any counselling services directed to subjects who served as individuals. Coaches must realize that athletes are independent individuals who have special characters to each other. In this case the coach must also realize that the cause of the problems athletes smoked between one athlete with athlete more certainly will not be the same. For that coach will also need more steeped in athletes personally to uncover the issues that happened on him. 
The orientation of the development; This means that each service is given notice the characteristics of the subjects who served from the side of the stage of its development. Coaches should understand that athletes faced in different degrees of development in accordance with the age groups that existed at the Club, a group of children will be different forms of treatment and prevention measures when compared to a group of teenagers, a midshipman and adult.

Orientation on the issue means that any counselling services are focused on the problem at hand. Coaches should understand that the counselling services provided is to develop effective life everyday (KES) and prevent the occurrence of Kes-T. Related to exercise and accomplishment that the coach should be able to develop a CASE of athletes optimally embodied in the implementation of training programs in the field leads to optimal achievement. Instead the coach as soon as possible undertake prevention if in the execution of the exercise took place obstacles, distractions and obstacles, including an athlete's behavior deviates like the habit of smoking.

By observing the orientation counselling conducted by the coach are expected to serve as:

Understanding that is the function of the counselling services in order to make the subject served to understand their own conditions and environment as well as a variety of contextual. In this case the coach is slowly but surely convinced that athletes as the subject is familiar with the conditions and the problems they face as including that they understand that the habit of smoking can impair the performance of the athlete to perform optimal approaches.

Maintenance and development of the functions of counselling services, namely to maintain and develop the positive conditions that exist on a subject that is served and directing on the life behavior of KES. This function means that the coach also made athletes that there are positive things in the athletes who should be on guard and keep develops he grew up like sportsmanship, perseverance, discipline and more. Coach in the event it is also need to emphasize the positive things as reinforcement of behavior that is in compliance with the KES.

Prevention, i.e. the function of the counselling services to prevent the development of conditions/negative has occurred on a subject that is served. Of smoking as one of the negative conditions should be attempted immediately prevented both to the athletes to be able to stop the smoking habit and also so that the habit is not emulated by other athletes

Reduction, i.e. the counselling function to overcome the negative conditions/KES-T into positive conditions (KES) back. Certainlythe responsibility to coach for the athletes who start trying or is familiar with the habit of smoking to stop it and athletes back to athletes with a pattern of behavior better and healthier.

The functions of Advocacy that is the function of the counselling services to re-establish the rights (the rights) subject that served the neglected or violated by the other party. In this case there are some athletes who are already considered smokers by his friends and began to set aside in the Association in place of exercise. In this case the coach sought to reinstate the athlete received in group practice through approach with athletes and members of the group, of course.

Some things that can be done by the coach to overcome and prevent athletes from smoking include:

Establishing effective communication between coaches and athletes;

Effective communication is communication that is capable of producing a change in attitude (attitude change) on the people involved in the communication between coaches and athletes. Effective communication is a twoway communication is not only from the coach, but also a coach capable of positioning as a good listener, who listen to any complaints over their fate and the problem of athletes. Effective communication not only in verbal language but most importantly should be reflected also from non verbal language such as body language, facial expressions that indicate the attention and support of the coaches against athletes.

Personal trainer approach related to the causes of these athletes why he smokes

Upon waking good communication will be born of confidence to be able to share problems, especially problems that plague the lives of the athletes themselves. Included also later how this proximity is the starting point of the coach to approach the approach in exploring the information related to the cause of these athletes smoke. It can be revealed if already built trust between coach and athlete.

Creating positive activities outside the training schedule.

Not only was the coach at the time of occurrence of the processes of mere exercise, where the interaction will happen coach give you referrals, orders, instructions and corrections and the athletes run in accordance with the directives or instructions given. Of course all of this is still perceived as a direct form of communication. But sometimes athletes need to also express themselves, identity as individuals are complex and evolving. It also required understanding to athlete outside of exercise activity. Understand athletes outside the context of exercise one is carrying out a variety of activities after hours athletes positive exercise. These activities in addition to enhancing the positive proximity between coach and athlete but can also control the athlete to perform leisure activities with a positive, too, can prevent athletes approaching the smoking habit.

Approach with the athlete's parents

Parents are the closest to the personal lives of the athletes, parents are the key figures who influenced the development of the athlete's personality. For that coaches need to establish good communication with parents in an effort to improve the performance of athletes and prevent negative behaviors one smoking behavior in athletes.

Provide information about the negative effects and hazards of the smoke.

Most teenagers are involved in smoking habits is ignorance or lack of information related to the negative impact of smoking. The coach obliged to submit 
information on the dangers of smoking information and its relation to the physical qualities of the athlete.

Self Awareness that athletes are human models through a variety of attributes that create pride in athletes..

The understanding that athletes are human beings or human models selected it is important because the need to instill pride that will awaken identity needed by the youth in the search for his true identity. As an athlete who performed with complete sports attributes will give pride that makes it different from other teenagers.

\section{CONCLUSION}

Cigarette smoking is the negative of its development activities from year to year continues to increase. Adolescents as young generation occupies the position was quite high and the trend continues to increase the amount being active smokers. Without exception the smoking habit is also epidemic to the athletes who continue to strive to maintain and improve the quality of its physical achievement in an effort that is optimal. Symptoms of athletes who started smoking (originally just trying even increased to addict) is a latent danger (hidden) which can impede the athletes to Excel even higher. Realized it needed understanding and prevention efforts of the coaches against athletes to protect themselves against the dangers of smoking athletes. Will certainly be wiser to prevent than treat. For that it takes the approach of the approach of counseling in an effort to prevent the symptoms of smoking habit in athletes. The coach as the man closest to the athletes of course requires understanding in this counselling approach, so as early as possible preventive efforts made efforts in preventing the emergence of a smoking habit initially still considered attempting to try by athletes.

\section{REFERENCES}

[1] Federici, F. M. Coaches' Coaching Competence in Relation to Athletes' Perceived. Journal of Education and Learning. 2013.pp 240-247.

[2] Erawan3, P. P. Efektivitas Metode Konseling Terhadap Perilaku Merokok Pada Siswa Sma Di Kecamatan Laeya Tahun 2015. Fakultas Kesehatan Masyarakat Universitas Halu Oleo, 2015.pp 9-67.

[3] Akil Hossain1, Q. Z.-u.-z. Factors Influencing Teenager to Initiate Smoking in South-west Bangladesh. Universal Journal of Public Health, 2015.pp 246-265.

[4] S., E. F. (2008, Februari 5). ardhana12.wordpress.com. Retrieved Maret 3, 2018, from https://ardhana12.wordpress.com/2008/02/08/metod e-penelitian-studi-kasus/

[5] Nururrahmah. Pengaruh Rokok Terhadap Kesehatan Dan Pembentukan Karakter Manusia. Seminar Nasional Pendidikan Karakter i, Palopo Sulsel. 2014.pp 77-88.
[6] Khurshid, F. Causes of smoking habit among the teenagers. Interdisciplinary journal of contemporary research in business. 2012.pp 851-897.

[7] Valeri Sot, Y. H. Influence of Parents on Child Behavior. BMC Public Health, 2013.pp 56-66.

[8] George Papathanasiou1, D. G. Effects of Smoking On Heart Rate At Rest And During Exercise, And On Heart Rate Recovery, In Young Adults. HJC (Hellenic Journal of Cardiology), 2013.pp 168-178.

[9] Prayitno. Dasar-dasar Bimbingan dan Konseling. Jakarta: Depdikbud. 1994.pp 34-56

[10] Kamaluddin. Bimbingan dan Konseling Sekolah. Jurnal Pendidikan dan Kebudayaan , 2011.pp 448449. 